\title{
KULTUUROPVOEDING EN DIE GEMEENSKAP: ENKELE CHRISTELIKE-WETENSKAPLIKE PERSPEKTIEWE. DEEL 2
}

\author{
P.G. Schoeman \\ Departement Wysgerige Pedagogiek en Andragogiek \\ Universiteit van die Oranje-Vrystaat \\ BLOEMFONTEIN
}

\begin{abstract}
In the previous anicle which touched upon the way in which noms for cultural development arc constituted by the analogical relationship which exists between the cultural mode of human existence and its superstnicture, i.e. all aspects of reality which are preceded in cosmic time by the cultural aspect, the possibilities of culturul enrichment pertaining to some post-historical modalitics of human existence have already becn explored. In this study the following cultural noms which are regnlative for cultural development and disclosure are considered: disclosed cultural balance, cuthurat hamony, cultural adjudication, cultural eros and cultural cenainty.
\end{abstract}

\section{TERUGBI.IK}

In die vorige artikel (Deel 1) het dit gegaan om die blootlegging van enkele beskawingsontwikkelingsnorme wat in 'n regulatiewe tydsrigting ten opsigte van die historiese aspek geleë is, en is die aandag toegespits op kultuurverdieping soos dit gekonstitueer word deur enkele na-historiese bestaanswyses van die opvoedeling. In die onderhawige artikel word gefokus op enkele oorblywende beskawingsontwikkelingsnorme wat in 'n regulatiewe, oftewel transendentale tydsrigting vanaf die historiese aspek van die werklikheid geleë is, naamlik die norme van kultuurekonomie, kultuurharmonie, kultuurberegting, kultuureros en laastens kultuursekerheid.

\section{ONTSIOTE EKONOMIESE SIN AS TEKEN VAN BESKAWINGSMONDIG IIEID}

Wanneer 'n kultuur differensieer en die onderskeie kultuursfere kom tot stand, is die handhawing van behoorlike (kultuur-)ewewig - die ekonomiese antisipasie binne die struktuur van die kultuurhistoriese - tussen hierdie kultuursfere uiters noodsaaklik ten einde wrywing en selfs botsing uit te skakel (vgl. Dooyeweerd, 1955:286). Immers, die gevalar bestaan steeds dat, tydens die proses van differensiëring, oormatige en eensydige klem geplaas mag word op die een of ander kultuursektor, hetsy kerk, staat, 
bedryf of wat ook al, en dat daar in ooreenstemming met hierdie eensydige beklemtoning, 'n "oordadige" (mags-)uitbreiding van so 'n lewensfeer plaasvind. In hierdie proses word die kosmiese grense van die onderhawige kultuursfeer oorskry, en word daarmee die normale en selfstandige ontplooiing van ander kultuursektore in die samelewing aan bande gelê en onder uiterste omstandighede selfs opgeskort. Hierdie skending van die beginsel van kultuurekonomie is dan ook die oorsaak van alle skeefgetrekte vorme van kultuurontwikkeling wat mag bestaan (vgl. Dooyeweerd, 1955:286, ook 190; Strauss, 1969:237; ibid., 1978:76).

In hierdie verband is dit die opgawe van letterlik alle instansies wat met die opvoeding van die kind te make het, en meer bepaaldelik dié van die skool, om 'n bydrae te lewer tot die vestiging by leerlinge van die beginsel van kultuurekonomie, onder andere deur toe te sien dat bepaalde aspekte van die eie kultuur nie oorbeklemtoon word ten koste van ander sfere van die kultuurgemeenskap oor die algemeen nie.

Kultuurekonomie is verder noodsaaklik sodat daar tussen die onderskeie kultuurkringe nie net behoorlike "afweging" sal plaasvind nie, maar juis ook dat verskillende kulture as van gelyke waarde en belang ten opsigte van die eie geag sal word en gevolglik ewewigtig langs mekaar sal kan bly bestaan sonder dat pogings aangewend sal word om mekaar te nivelleer.

* Regulatiewe verdieping van die ekonomiese vind plaas wanneer dit onder leiding van die estetiese verdiep tot ekonomiese harmonie, dit wil sê wanneer 'n mens nie te vrekkerig of te spandabelrig met betrekking tot sy besittings, sy tyd, energie, emosies en so meer optree nie; wanneer hy enersyds nie oordrewe waarde heg aan stoflike besittings nie, dog dit andersyds ook nie total minag nie. Hy moet vrygewig wees, dog ook genoeg versamel om aan minderbevoorregtes uit te deel.

* Vanuit die juridiese ontsluit die ekonomiese tot ekonomiese beregting, dit wil sê wanneer die mens dermate ontslote is dat hy sy medemens nie ekonomies sal uitbuit nie, geen woekerwins sal aanvaar nie, nie omkoopbaar is nie, sy werknemers genoeg sal betaal, nooit ekonomies egoïsties is nie. Hy moet nie net vir homself werk en versamel nie, maar moet juis ook ywerig in diens staan van die belange van ander persone asook alle sektore van die gemeenskap in die breë.

- Vanuit die etiese ontsluit die ekonomiese tot ekonomiese liefde, dit wil sê waar liefde vir die stoflike nie oordrewe is soos die geval van die ryk dwaas wat, in die ydele hoop op 'n onbekommerde aardse lewe, sy skure volgemaak het en nie aan sy siel gedink het nie. Wat ekonomies haalbaar is moet op normatiewe wyse nagestreef word, en nooit ten koste van die natuur, die kultuur, die medemens of die samelewing oor die algemeen nie. 
* Uiteindelik ontsluit die ekonomiese onder leiding van die ontslote geloof tot offervaardigheid in die diens van God en die medemens: die mens is immers nooit werklik eienaar nie, dog slegs rentmeester. Ook sy ekonomiese besit moet aan God as die Gewer van alle goeie dinge en voorspoed gewy word (vgl. Schoeman, 1983:231-232)

\section{ONTSLOTE ESTETIESE SIN AS TEKEN VAN BESKAWINGSMONDIG- HEID}

In antisipasie van die estetiese, en teen die agtergrond van kultuurekonomie, ontsluit die kulturele tot kultuurharmonie (vgl. Dooyeweerd, 1955:287). Dit beteken dat daar tussen die ten volle gedifferensieerde kultuurterreine in 'n moderne en ontslote samelewing 'n onontbeerlike kultuurharmonie aanwysbaar sal wees wat die waarborg vir 'n spanninglose saambestaan op kultuurgebied is. Inderdaad, oormatige en onewewigtige (ekonomies antinormatiewe) magsuitbreiding deur enige samelewingsverband sal aanleiding gee tot disharmonie (esteties antinormatief) in die voortgaande kultuurontwikkeling van 'n gemeenskap, net soos ongebalanseerde magsuitbreiding deur dominante kulture in 'n multi-kulturele gemeenskap sonder meer tot ernstige kultuurdisharmonie lei. Gehoorsaamheid aan die beginsel van kultuurharmonie bied die waarborg dat sowel die aard-eie ontwikkeling van onderskeie samelewingsverbande (kerk, staat, bedryf, tegniek, wetenskap en so meer), as die kultuurontwikkeling van die onderskeie kultuurgemeenskappe ongesteurd sal kan voortgaan en sal kan ontvou in die historiese proses van kultuurdifferensiasie (Dooyeweerd, 1955:287). Indien daar in 'n kultuurgemeenskap sprake is van kultuurharmonie, beteken dit dat geen enkele kultuursfeer pogings aanwend om die grondnoemer van die res te word of om hulle op totalitaristiese wyse op te slurp nie. Gehoorsaam aan die beginsel van kultuurharmonie ontstaan 'n normale gemeenskap, volledig gedifferensieerd op die grondslag van nieinmenging; sonder enige totalitaristiese neigings (Dooyeweerd, 1955:287). Slegs langs hierdic weg kan uitgestyg word bo die vlak van onontslote sosialisme en primitiewe totalitarisme, en sal kultuurontwikkeling nooit disharmonies, dit wil sê in stryd met die historiese norm van kultuurharmonie verloop nie (vgl. Strauss, 1969:237).

Dit is dan sonder meer duidelik dat magsuitbreiding binne die perke (dit wil sê in gehoorsaamheid aan die normatiewe eis) van tipiese struktuurbeginsels wat geld vir die onderskeie samelewingsterreine as sodanig nooit tot disharmoniese kultuurontwikkeling aanleiding kan gee nie. Kultuurkonflik ontstaan slegs waar die aard-eie grense van samelewingsterreine geïgnoreer en gevolglik oortree word (Dooyeweerd, 1955:287). Die waarheid is eerder dat die onderskeie samelewingsterreine mekaar se hulp en ondersteuning nie kan ontbeer nie, maar dat hierdie hulp en ondersteuning op sigself van weinig waarde is indien die eie-aard daarvan op enige wyse negatief 
aangetas en verander word (vgl. Dooyeweerd, 1955:287-288).

In opvoedingsverband beteken dit dat die ideaal van kultuurharmonie by die leerling vasgelê behoort te word. Deur die positiewe toepassing van die beginsel van kultuurharmonie word die moontlikheid inderdaad geskep vir latere spanningsvrye kultuurontwikkeling, asook vir 'n harmoniese en spanningsvrye saambestaan van kultuurvorme (Dooyeweerd, 1955:287).

Die opvoedeling moet ervaar dat daar bepaalde terreine is waarop die onderskeie samelewingsvorme met eiesoortige gesag spreek. So kom hy tot die besef dat die kerk, staat, huisgesin, skool, universiteit ensovoorts elk 'n eie rol in die kultuurgemeenskap besit wat hy die beste kan hanteer, en dat hy sélf - as beskawingsmondige en ontslote persoonlikheid - die nodige agting vir hierdie beginsel sal betoon.

* Die estetiese aspek word juridies verdiep sodra die kwessie van sensuur (as vorm van beregting) in die kuns ter sprake kom. Die kind moet esteties ontsluit tot estetiese regverdigheid of estetiese beregting, wat beteken dat hy sal weet wat esteties "mag" en wat nie (vgl. Steensma \& Van Brummelen, 1977:75-76). Dit is uiters problematies om te bedink dat persone blootgestel word aan alle fasette van die moderne, kultuur- en maatskappy-krities ingestelde kuns, voordat hulle dermate esteties en andersins ontslote is dat hulle die volle skerpte en trefwydte van die aanslag teen die gevestigde orde met sy skynheiligheid, selfsug en dubbele standaarde kan hanteer (om byvoorbeeld te besef dat banaliteite nie om hul eie ontwil gebesig word nie, maar om moontlik daarmee 'n bepaalde boodskap oor te dra).

* Etiese verdieping vind verder plaas wanneer liefde vir die kuns en álle vorme van kunsuiting gekweek word, sodat kunsprodukte ook daarop ingestel is om nie onontslotenes te laat verdwaal nie, en die kuns onder alle omstandighede eerlik en krities, dog terselfdertyd ook verheffend sal wees.

* Onder leiding van die ontslote geloof word die ideaal van Christelike kuns gebore en stuur kunsopvoeding op skool af op die positivering van Christelike (nie "godsdienstige" nie) norme in die kuns dog ook in die onderskeie vorme van kunskritiek (vgl. Schoeman, 1983:232-234).

4. ONTSLOTE JURIDIESE SIN AS TEKEN VAN BESKAWINGSMONDIGHEID

In die gedifferensieerde kultuurgemeenskap kan - soos hierbo gesien - elke afson- 
derlike kultuursfeer sy besondere rol effektief en vry vervul slégs indien daar sprake is van kultuurekonomie en kultuurharmonie. Langs hierdie weg word inderdaad die regmatige rol van elke kultuurvorm gewaarborg teen grensoorskryding van die kant van ander kultuurvorme. Wanneer die juridiese antisipasie binne die struktuur van die kultuurhistoriese ontsluit tot wat goedskiks as kultuurberegting (vgl. Dooyeweerd, 1955:289-290) bestempel kan word, word 'n bydrae gelewer tot die gelykberegting van elke kultuursfeer ten opsigte van die res, en word 'n situasie geskep waarin elke kultuursfeer sy regmatige rol onbelemmerd sal kan vervul (Strauss, 1969:237-238; ibid., 1978:76).

Dooyeweerd wys dan ook pertinent daarop dat, indien daar disharmonie tussen die kultuurkringe binne 'n samelewing bestaan as gevolg van die oortreding van die beginsel van kultuurekonomie, die onontbeerlike kultuurharmonie wat 'n spanninglose "saambestaan" van samelewingsverbande waarborg, versteur word en kultuurontwikkeling onvermydelik disharmonies, dit wil sê op esteties antinormatiewe wyse moet verloop. Indien dít die geval is, ontstaan daar later verset teen die grensoorskryding van die oorheersende kultuurvorm, en word daar uiteindelik 'n gerig in die kultuurontwikkeling van 'n gemeenskap voltrek deurdat die oorheersende kultuursfeer uiteindelik deur die gesamentlike mag van die oorwoekerde kultuursfere uitgeskakel word. In gevalle van ernstige stryd in hierdie verband kan dit inderdaad aanleiding gee tot die totale ondergang van só 'n uiteengeskeurde kultuur (Dooyeweerd, 1955:290; vgl. ook Strauss, 1978:76).

In opvoedingsverband is dit duidelik dat historiese of kulturele beregting hier ter sprake kom. Die opvoedeling moet die besef ontwikkel dat indien die kultuurbeginsels van kultuurekonomie en kultuurharmonie verontagsaam word, 'n reaksie noodwendig sal volg. Die noodsaaklikheid van behoorlike normatiewe binding is hier maar te duidelik. Die opvoedeling moet tot die besef kom dat daar Goddelike norme is wat vir die bestaan van die onderskeie kultuurterreine geld.

'n Persoon is juridies ontslote wanneer hy

* reg en geregtigheid in liefde voltrek; wanneer liefde met ander woorde op ekspansiewe wyse met betrekking tot die juridiese die leiding sal verkry sodat vergelding altyd aan billikheid (die oorweging van regsgronde, bepaalde omstandighede, toerekeningsvatbaarheid en so meer) gekenmerk en deur genade getemper sal word, want die beginsel van 'n oog vir'n oog en 'n tand vir'n tand het geen plek in ' $n$ juridies-ontslote (deur liefde en geloof) gemeenskap en onder juridies-ontslote mense nie.

* Uiteindelik verdiep die juridiese bestaanswyse van die opvoedeling in sy regula- 
tiewe verbintenis met die geloofsmodaliteit wanneer dit deur die Christelike geloof gelei word tot 'n aanvaarding van die beginsel dat reg en geregtigheid deur God gegee is en derhalwe vir alle tye vas en seker stuan, en dat die uitoefening daarvan deur mense slegs in onderworpenheid aan die Goddelike ordinering wat daarvoor geld mag geskied; dat menslike gesag slegs relatiewe, verleende en relasionele gesag is; dat die wraak (vergelding) in die laaste ontleding die mens nie toekom nie. Immers, ook die mens self leef slegs uit genade (vgl. Schoeman, 1983:234-235).

\section{ONTSLOTE ETIESE SIN AS TEKEN VAN BESKAWINGSMONDIGHEID}

Die etiese antisipasie binne die struktuur van die kultuurhistoriese verskyn in die moment van kultuurliefde betreffende die mens se vormingstaak en -arbeid in die voortgaande beskawing van die mensheid (vgl. Dooyeweerd, 1955:152). Dit impliseer in die besonder liefde vir die normatiewe in die eie kultuur, waarby inbegrepe is liefde en agting vir die kulture en kultuurerfenisse van ander, asook permanente trou en lojaliteit daaraan (Dooyeweerd, 1955:291; vgl. ook Greene, 1977:12-13). Kultuurliefde dui dan op wat Strauss noem die "gedifferensieerde liefde waarmee elke kultuurvormer sy kultuurtaak in elke lewensfeer vervul" (Strauss, 1969:238; ibid., 1978:76). Hierdie sogenaamde kultuureros, synde "love for this cultural call as a real formative power in history" (Dooyeweerd, 1955:291), dryf die kultuurvormer steeds verder op sy weg na toegewyde liefdesarbeid in normatiefvrye lewensfere (Strauss, 1969:238). Hiersonder het nog geen grootse kultuurprestasie in die beskawingsgeskiedenis van die mens tot stand gekom nie. Dog ook hierdie kultuurbeginsel is direk afhanklik van die erkenning van die beginsels van kultuurekonomie, -harmonie en -beregting, anders verval kultuureros spoedig tot afgodediens (Dooyeweerd, 1955:291). Enige antinormatiewe manifestering van kultuurliefde lei onvermydelik tot wat Dooyeweerd "kultuurskuld" noem, en wat gewreek word deur kultuurspanninge, kultuurkonflikte en kultuurkatastrofes (1955:291). Sou gedifferensieerde kultuursektore dan onderwerp word aan die dwang van 'n buite-instansie, soos byvoorbeeld in gevalle waar kultuur in opvoedingsverband aangewend (gemanipuleer, misbruik) word met die oog op buite-opvoedkundige - byvoorbeeld partypolitieke - doeleindes, word "beskawingselfstandige kultuurskepping" in die kiem gesmoor, omdat onder dergelike omstandighede die noodsaaklike liefde vir kultuurarbeid geheel en al ontbreek (vgl. Dooyeweerd, 1955:152; Strauss, 1978:76).

By die opvoedeling moet die idee van 'n vrye staat, vrye kerk, vrye skool, vrye huisgesin en so meer onder Gods oorkoepelende skeppingswet gekweek word, want langs hierdie weg sal verseker word dat 'n samelewing tot stand kom wat totalitarisme - vanuit watter oord ook al - in beginsel sal bestry. Immers, predikante en lidmate van die kerk kan alleen hulle kerklik-godsdienstige lewe voluit leef as die kerk nie deur die staat 
oorheers word nie; die onderwyserskorps kan alleen as professionele persone hulle opvoedingstaak doeltreffend uitvoer indien hulle nie deur die owerhede tot die peil van onprofessionele arbeiders gedegradeer word nie, ensovoorts.

* Die opvoedeling moet, onder die verdiepende en ontsluitende leiding van die ontslote geloofsfunksie met sy geloof en vaste vertroue in God deur Christus eties ontsluit sodat hy - soos God dit van hom eis - sy naaste sal liefhê soos homself, en by implikasie ook die ganse tydelike wêreld. Uitbuiting, onderdrukking, minagting, vernielsug en dergelike hoort by geen beskawingsmondige, eties-ontslote persoonlikheid tuis nie. Die etiese mag egter ook nie in blote moralisme verval nie, want as sodanig is dit eensydig en onderhewig aan willekeur en veranderende omstandighede en lewensmilieu. Onder leiding van die ware geloof waardeur die sedelike eis as 'n Godgegewe opdrag vir intermenslike verhoudinge opgeneem word, kan etiese opvoeding van alle moralisme gevrywaar word en waarlik as opvoeding tot liefde wat uit ware geloof opkom, bestempel word. Die opvoedeling moet opgevoed word tot ware liefde vir homself, vir sy medemens, sy tydelike wêreld waarvan kerk, staat, huisgesin, vaderland, moedertaal ensovoorts deel uitmaak. Selfs die liefde tussen jongmense, man en vrou, ouer en kind word in hierdie lig gesien as deur God Self verordineer. Hy het immers hierdie saamwees van mense van die begin af só bepaal (vgl. Schoeman, 1983:235-236).

\section{ONTSLO'TE GELOOF AS TEKEN VAN BESKAWINGSMONDIGHEID}

Geloof is in die laaste instansie die leidende funksie ten opsigte van die ganse proses van kultuurontsluiting (Dooyeweerd, 1955:291, 298). In die proses van beskawingsontwikkeling kan verskillende regulatiewe "ideë" (behorende tot die onderskeie kultuurterreine van die menslike bestaan) die leiding tydens kultuurontsluiting neem en tot ' $n$ heel besondere soort kultuur en kultuurontwikkeling aanleiding gee (vergelyk byvoorbeeld die idee van wetenskap: wetenskapskultuur; die idee van tegniese beheersing van die natuur: tegnokratiese kultuur; die idee van groepsgebondenheid en bepaaldheid: sosialistiese kultuur; die idee van ekonomiese welvaart: welvaartskultuur; die idee van skoonheid: estetistiese kultuur; die idee van naasteliefde: moralistiese kultuur; die idee van totale kerklike betrokkenheid: piëtistiese kultuur). Omdat dit egter, in die finale ontleding, op die geloofsaspek is waarop die ganse proses van kultuurontsluiting appelleer (Dooyeweerd, 1955: 291), is die besondere aard en rigting van hierdie leidinggewende geloof van kardinale belang wanneer oor die aard en ontwikkeling van kulture besin wil word.

Kragtens sy posisie as transendentale terminale funksie van die ganse proses van kultuurontsluiting, is elke vorm van geloof, ongeag die aard of rigting daarvan, steeds 
direk gedrewe deur die religieuse wortel van menslik eksistensie, "either for good or for evil" (Dooyeweerd, 1955:293). Strauss stel dit só dat die geloofsfunksie van die mens religieus in die menslike selfheid verwortel is, en om hierdie rede ontvang dit steeds vanuit die een of ander religieuse grondmotief 'n sentrale gerigtheid wat die menslike selfheid midde in die antitese, dit wil sê die stryd tussen die Lig en die duisternis plaas, aangesien die menslike selfheid slegs gerig kan wees of op die ware Oorsprong van alle dinge, of op die een of ander vermeende (gewaande) oorsprong daarvan wat - in afvallige hartsgegrepenheid - in die skepping sélf gevind word (Strauss, 1969:238; ibid., 1978:76-77).

Die ontsluiting van die pistiese antisipasie binne die struktuur van die kultuurhistoriese bring die norm van kultuursekerheid in die blikveld (vgl. Dooyeweerd, 1955:291). Kultuursekerheid kan omskryf word as 'n vaste oortuiging dat die kulturele aspirasies van ' $n$ bepaalde kultuurgemeenskap in ooreenstemming is met die wil van die Skepper daarvoor; dat dit met ander woorde 'n normatiewe beantwoording is van die oproep aan die mens om sy kultuurmandaat op normatiewe (Godwelgevallige) wyse uit te voer. Dit is dan 'n onwrikbare sekerheid in die hart van die mens dat hy 'n kultuurtaak besit en dat sy kultuurarbeid steeds die toets van die Goddelike wêreldorde en die Heilige Skrif moet kan deurstaan.

Omdat kultuurontwikkeling altyd plaasvind in die verlengde van bepaalde religieuse dryfkragte (vgl. Van der Walt et al., 1983:149), staan kultuursekerheid verder in verband met die oortuiging dat die kultuurdominante mag wat die kultuurontwikkeling van 'n bepaalde kultuurgemeenskap lei, dit uiteindelik sal rig op die algemene heil van die mensheid, en beslis nie op sy vernietiging nie. In hierdie verband is dit byvoorbeeld sonder meer duidelik dat die ekologiese krisis van ons tyd veroorsaak is deur 'n kapitalisties georiënteerde, scientisties-tegnokratiese welvaarts- en uitbuitingskultuur wat in alle opsigte gedrewe is deur ' $n$ nie-Christelike grondmotief (vgl. Schoeman, 1982:147-153; Schuurman, 1975:23-24;26-30). Die religieuse antitese waarvan hierbo melding gemaak is, tipeer die heersende kultuurmagte van ons tyd dan inderdaad ook as oorkoepelend Christelik of nie-Christelik (vgl. Schuurman, 1972:337-346; Strauss, 1969:239; ibid., 1978:78). So staan ook die historiese ontsluiting by die opvoedeling dan uiteindelik onder die leiding van 'n ontslote geloofsmodaliteit wat meebring dat die beginsels en rigting wat daardeur aan historiese ontwikkeling gegee word, van Christelike of nie-Christelike aard is.

Aangesien die humanistiese wetenskapsideaal (vgl. Schuurman, 1972:188ff; Schoeman, 1982:147-153) ongetwyfeld neerslag gevind het in die tegnies-wetenskaplike kultuur van ons tyd en hier te lande, het dit 'n saak van besondere aktualiteit en dringendheid geword dat die skool aan leerlinge 'n Bybelsgefundeerde, Christelike perspektief sal bied op die kultuur, met besondere klem op die kultuurmandaat en die normatiewe 
opgawe en eise wat dit vir die Christen se vormingsarbeid inhou. Inderdaad, as daar iets is waaraan die moderne mens wat hom daagliks bevind in wat al bestempel is as die "krisis van die sekerhede" 'n behoefte het, dan is dit ongetwyfeld onwrikbare geloof in, en vertroue op die Vaste Grond. Dit is dan in die lig hiervan dat die opvoedingstaak van die skool van ons tyd om die opvoedeling te begelei tot die besitname van onwrikbare sekerhede aangaande die Oorsprong van alle dinge die nodige reliëf $\mathrm{kry}$ (vgl. Strauss, 1978:78; ook Schoeman, 1983:237-238).

\section{PERSPEKTIEF}

Die aktualiteit en onontbeerlikheid van behoorlike kultuuropvoeding vir alle persone in hierdie land, asook die taak van die skool as opvoedingsinstansie in hierdie verband is - in die lig van wat hierbo aan die orde gestel is - onontkenbaar. In die voorgaande gedeeltes is by herhaling gewag gemaak van die onderskeie samelewingsvorme waarin die beskawingsmondige mens sy gedifferensieerde lewenstaak moet vervul. In hierdie ontslote, volledig gedifferensieerde samelewing met sy ingewikkelde spektrum van samelewingsvorme moet die beskawingsmondige persoon voluit deel hê aan die rykdom van sosiale verhoudinge wat hom gebied word. Tot hierdie "deelhebbing" moet hy egter opgevoed word sodat hy in die rykste en omvattendste sin van die woord in variërende omstandighede en in die lig van die besondere eise wat hierdie gedifferensieerde gemeenskap op hom lê, tot God se eer kan leef, dit wil sê in volledige normgehoorsaamheid (Schoeman, 1983:240-241).

Kultuuropvoeding op skool, kultuuropvoeding in sy omvattendste sin wat uiteindelik die totale ontsluiting van alle fasette van die kind se persoonlikheid ten doel het, moet dan beskou word as die korrekte "invalspoort" vir opvoeding met die oog op die kind se toekomstige normatiewe optrede in die ingewikkelde wêreld buite die skool, aangesien die graad en gehalte van individuele ontslotenheid van die mens bepalend gaan wees vir die wyse waarop hy gaan optree in die verskillend-geaarde samelewingsvorme waarin norme en beginsels telkens "anders" (dit wil sê op aard-eie wyse) tot vergestalting kom (Schoeman, 1983:241). Ontsluiting tot onderskeiding met betrekking tot die besondere eise van die verskillende samelewingsvorme begin reeds tuis, maar word veral op skool verder voortgesit en verdiep, en wél in terme van die wye verskeidenheid van verbintenisse waarin die opvoedeling hom deurgaans bevind, en wat ' $n$ voorspel is tot die hoogs gedifferensieerde gemeenskap waarin hy uiteindelik moet leef. Akkurate onderskeiding van die tipiese wyses waarop dieselfde norm byvoorbeeld in die onderskeie samelewingsvorme tot vergestalting kom, stel inderdaad hoë eise aan die onderskeidingsvermoë van die beskawingsmondige persoon (vgl. Schoeman, 1980: 144 - 146; ibid., 1983: 241 - 242). 
Kultuuropvoeding en die gemeenskap 2

\section{BIBLIOGRAFIE}

DOOYEWEERD, H. 1955. A new critiquc of theoretical thought. Vol. II. Amsterdam : Paris . GREENE, A.E. 1977. Norms and objeclives for Christian education. (In Steensma, G.J. \& Van Brummelen, H.W. Shaping school curriculum. Terre Haute : Signal. p. 4-19.)

SCHOEMAN, P.G. 1980. An introduction to a philosophy of education. Durban : Butterworths. SCHOEMAN, P.G. 1982. Culture, society and education - the quest for alternatives. South African Joumal of Education, 2(4):147-153.

SCHOEMAN, P.G. 1983. Wysgerige Pedagogiek. Blocmfontcin : Sacum .

SCHUURMAN, E. 1972. Technick en tockomst. Assen : Van Gorcum.

SCHUURMAN, E. 1975. Na-denken over de technisch-wetenschappelijke kultuur. Ongepubliseerde Intrecrede. Amsterdam : Vrije Universiteit.

STEENSMA, G.J. \& VAN BRUMMELEN, H.W. 1977. Shaping school curriculum. Terre Haute : Signal.

STRAUSS, D.F.M. 1\%69. Wysbegecrte en vakwetenskap. Blocmfontein : Sacum

STRAUSS, D.F.M. 1978. Inleiding tot dic kosmologie. Bloemfontein : Sacum.

VAN DER WALT, J.L., DEKKER, E.I. \& VAN DER WALT, I.D. 1983. Dic opvoedingsgebeure : 'n Skrifmatige perspektief. Instituut vir Reformatoriese Studies, Nr. 18. Potchefstroom : PU vir CHO. 